DOI: https://doi.org/10.31933/dijms.v2i3 Received: 30 June 2020, Revised: 21 November 2020, Publish: 22 January 2021

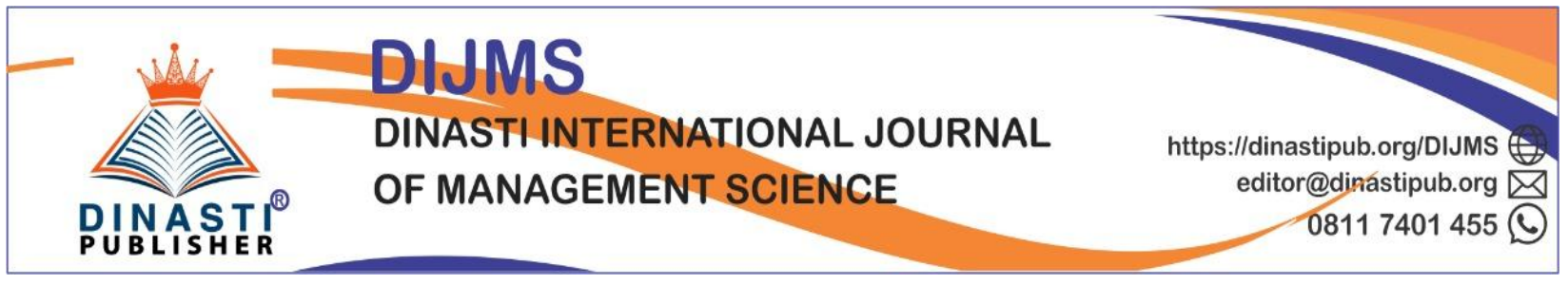

\title{
MANAGEMENT OF THE OIL AND GAS INDUSTRY IN INDONESIA MANAGERIAL PERSPECTIVE (STUDY IN THE INDONESIAN UPSTREAM OIL AND GAS INDUSTRY)
}

\author{
Kasman Arifin ${ }^{1}$, Dina Hidayat ${ }^{2}$, Iqbal Maulana Arifin ${ }^{3)}$ \\ 1) Universitas Islam Riau, Pekanbaru, Indonesia, kasmanarifin@eco.uir.ac.id \\ ${ }^{2)}$ Universitas Islam Riau, Pekanbaru, Indonesian, \\ ${ }^{3)}$ Politeknik Caltex Riau, Pekanbaru, Indonesian,
}

Corresponding Author: First Author

\begin{abstract}
This article discusses the organization of upstream oil and gas industri in Indonesia from managerial perspective. For Indonesian context, actually this has been arranged by the Statement Oil and Gas Standard Accountancy No.29 Year 2009. In developed countries such as United States there is Standard Financial Accounting Statement issued by Financial Accounting Standard Board (FASB). In order to obtain clarity and transparency and to avoid different interpretation between the contractors and the government, therefore there ought to be explicit principles and methods in production sharing contract and desired accountancy period so that the similar method can be applied on APBN (National Planning and Expenditure Budget). This is since accountancy method affects financial report. With the latter, contractor's performance and state income can be measured. Research methodology are ground research and exploratory research, reaseacher assumption based on field condition and resolve problem from literature study.
\end{abstract}

.Keywords: The Organization of Upstream Oil and Gas Industry, Oil \& Gas Aaccounting, Managerial Perspective.

\section{INTRODUCTION}

In the upstream oil and gas industry, there are three things that must be provided by companies, namely money, experts and technology. These three components must be managed in such a way that the company can achieve its objectives.

The latest development in management theory states that a company can be seen as an open system because in its life the company always interacts with its environment. The corporate environment can be divided into two groups, namely: (1) general environment such as economy, politics, technology, law, culture, (2) specific environment such as consumers, company output, suppliers of raw materials, competitors certain technologies, the labor market, and financial institutions.

Yuwono, S (2004:31) said that traditionally, financial statements are historicalaggressive indicators that reflect the results of the implementation and execution of corporate 
strategy in a period. Measurement of financial performance will show whether the planning and implementation of strategies provide fundamental improvements for company profits. These improvements are reflected in goals specifically related to measurable profits, business growth and shareholder value.

Modern financial management theory states that the company's goal is to maximize the shareholders' wealth, which translates into the goal of maximizing the company's ordinary share price.

Companies as organizations that use and coordinate economic resources to satisfy needs by obtaining profits, also have a strategy. The company's strategy can be expressed from the company's objectives. The main goal of the company is survival (then can survive), then followed by other goals. In general, there are two corporate objectives, namely commercial goals and social goals.

Strategies to achieve commercial goals and social objectives are outlined in the contractual form.

Contractual theories about the nature of the company are now increasingly widely used. This theory views companies as a network of contracts, actual and implied, which establish the roles of various participants or risk holders (workers, managers, owners and lenders) and determine their rights, obligations and rewards under various conditions. Although contracts determine the rights and responsibilities of each group of corporate risk holders, potential conflicts occur because participants also have personal goals.

Financial management is the application of management functions in the financial sector, meaning that the functioning of the financial department is a prerequisite for the smooth implementation of activities in other parts of a company's scope.

Based on the description above, it can be concluded that in the upstream oil and gas industry which is full of capital, expertise and technology, financial management or management is needed to coordinate resources optimally and maximize shareholders' wealth through commercial businesses which are translated in the form of cooperation contracts, therefore The company's performance can be measured.

The following part will discuss management of upstream oil and gas management and recording methods in the oil industry that have a unique business character. The recording or accounting method is the most important part in the management of the upstream oil and gas industry. This method of recording is also one of the most important elements (indicators) of the fiscal system in Indonesia. This paper aims to determine whether the revenue-sharing funds obtained by oil and gas producing regions have a significant influence on the Regional Revenue and Expenditure Budget (APBD). The results of the study are expected to contribute to policy makers related to the upstream oil and gas industry.

\section{LITERATURE REVIEW \\ Indonesian Upstream Oil \& Gas Industry}

Considering the strategic role of oil and gas in national development, the government on August 20, 1968 decided that oil and gas exploitation must be carried out by a state 
company. The company appointed to carry out the government policy is the National Oil and Gas Mining Company (PN Pertamina).

According to Law No. 8 of 1971, Pertamina is responsible for managing Indonesia's oil and gas resources in all related aspects such as exploration, exploitation, production, processing, transportation and sales of oil and gas.

Pertamina can cooperate with other parties, while the forms of cooperation include:

1) Contract of work, in this contract the distribution is based on profits, while management and ownership of assets are in the hands of contractors.

2) Production sharing, management and asset ownership contracts are in the hands of Pertamina, which is divided into production after deducting operating costs.

Post Law No. 22/2001, all arrangements and forms of agreements in the upstream oil and gas industry have changed drastically, Pertamina's authority has been cut. The authority in the upstream sector is handed over to the Oil and Gas Implementing Agency (BP MIGAS) while downstream is given to the Regulatory Agency (Legal Review No. 35 / TH III August 2005, 11).

The soul of the provisions of the Production Sharing Contract Article can be seen from the scope of the existing contract, consisting of five main paragraphs, namely:

- Paragraph 1 This contract is a production sharing contract.

- Paragraph 2 BPMIGAS will have rights and responsibilities for operations management, and the contractor is responsible for oil and gas operations.

- Paragraph 3 The contractor provides all financing and technical assistance.

- Paragraph 4 The contractor bears the risk of operating costs and interest costs incurred to finance operations.

- Paragraph 5 Throughout the agreement in the contract, the total production is divided into sequences.

Regarding profit sharing in the PSC (Production Sharing Contract) it is a matter that is always being negotiated. For Indonesia, it still adheres to the law, that in making contracts, it must always prioritize the interests of the nation. (Ernst G. Tehuteru, Legal Review No. 35 / TH III August 2005, 32).

Looking at the development of the contract of work model or production sharing contract or cooperation contract, the dominance of foreign parties or the influence of investors is very thick, even for the first generation contract the concept is made by the company's legal experts concerned.

In order to make this cooperation contract appeal to foreign investors, various ways are carried out by the government by providing incentives. So that this incentive does not reduce and guarantee government revenue, the contractual obligation includes the contractor's obligation to deliver his first production, known as First Tranch Petroleum (FTP) and so that the supply of oil and gas for domestic needs is guaranteed, a regulation known as the Domestic Market Obligation. 


\section{Oil \& Gas Accounting}

The Indonesian Institute of Accountants (IAI) on 7 September 1994 issued a statement specifically intended for petroleum businesses which explained in its scope and application that (PSAK No. 29, 1994: 29.3):

1) Statement of Oil and Gas Accounting Standards. Where this statement is compiled based on the nature and characteristics of the Indonesian petroleum business and is guided by the basic accounting concepts contained in Financial Accounting Standards and applicable laws and regulations.

2) This statement is intended to be used as a guide in the presentation of financial statements for external parties. In this sense, an assumption is implied that both the compilers and users of financial statements need the same standard in the preparation and presentation of company reports.

3) This statement regulates the accounting for exploration or search, development, production, processing, transportation, marketing and other activities in the oil and gas industry.

4) For oil and gas contractors working according to contracts with the government / Pertamina, this statement can be used, as long as the accounting treatment is not specifically regulated in the contract concerned. In the event that the contract specifically regulates the accounting treatment of a transaction, the contract conditions apply.

In carrying out oil and gas exploration and production activities there are 4 (four) components of costs that generally occur in oil companies, and the recording is done based on the prerequisites that exist in oil accounting. The four general costs are:

1. Acquisition Cost.

Acquisition costs are incurred in connection with the company's efforts to acquire property (the right to conduct the oil and gas industry in an area / area).

2. Exploration Cost.

Exploration costs are incurred in an effort to explore (search for oil and gas and geothermal) on a property.

3. Development Cost.

Development costs are incurred in relation to activities to prepare / obtain proved reserves (proven reserves) to be ready for commercial production.

4. Production Cost (Production Costs).

Production costs are associated with lifting activities (lifting oil, natural gas, geothermal, and other minerals to the surface which consist of, among other things, from the drainage costs of the first, second and third stages), collection in a landfill tank, separation of oil, natural gas and water-based deposits, treating and storing oil and gas in storage tanks to be ready for market.

Gallun, RA, $(1993 ; 36)$ said that there are two generally accepted cost methods that cover four basic costs, namely: successful-efforts accounting (SE) and full-cost accounting (FC). 
Based on Generally Accepted Accounting Principle (GAAP) and Statement of Financial Accounting Standards (PSAK) No. 29 there are two methods of recognition that can be used, namely:

1. Full Costing (FC) Method

2. Successful Effort (SE) Method

The emergence of this thinking is caused by various things that cause controversy among the oil industry, especially those concerning accounting treatment of exploration activities and costs. which is full of elements of speculation.

Petroleum analysts understand that accounting methods have an impact on financial statements. Income for companies that use FC is generally not the same compared to companies that use SE. Companies that use FC pay a price to get a relatively higher opportunity. They have to pay higher taxes. (Johnston, D., Et al. 1998; 37).

\section{Managerial Perspective}

In the upstream oil and gas industry, there are three things that must be provided by companies, namely money, experts, and technology. These three components must be managed in such a way that the company can achieve its objectives.

The latest development in management theory states that a company can be seen as an open system, because in its life the company always interacts with its environment. The corporate environment can be divided into two groups, namely: (1) general environment (general environment) such as economy, politics, technology, law, culture, (2) specific environment (specific environment) such as consumers, company output, suppliers of raw materials, competitors , certain technologies, the labor market, and financial institutions. (Awat, NJ 1998; 1).

Yuwono, S. (2004: 31) said that traditionally, financial statements are historicalaggressive indicators that reflect the results of the implementation and execution of corporate strategies in a period. Measurement of financial performance will show whether the planning and implementation of strategies provide fundamental improvements for company profits. These improvements are reflected in goals specifically related to measurable profits, business growth and shareholder value.

Modern financial management theory states that the company's goal is to maximize the shareholders' wealth, which translates into the goal of maximizing the company's ordinary share price. (Awat, NJ 1998; 3).

Companies as organizations that use and coordinate economic resources to satisfy needs by obtaining profits, also have a strategy. The company's strategy can be expressed from the company's objectives. The main goal of the company is survival (then can survive), then followed by other goals. In general, there are two corporate objectives, namely commercial goals and social goals. (Siagian, YM, 2005; 17).

Strategies to achieve commercial goals and social objectives are outlined in a contractual form. 


\section{Previous Research}

Xiaojie Xu (2002) conducted research on China's strategy in managing and searching for oil energy sources. He examined and described how the strategies carried out by China in managing and searching for oil energy sources in the Middle East region, which are related or in contact with macro (political policy), economic, social, cultural and religious) and their impact on the energy supply, security and price of the energy itself.

The research method used by researchers is exploration, where researchers explore all aspects related to energy management, including the management of natural resources outside mainland China through companies whose majority ownership is owned by the government.

The results of this study are:

a.To penetrate the upstream sector in the Middle East region, the Chinese government is helping to take a diplomatic approach and draft contracts for countries such as Saudi Arabia and Kuwait so that they can invest safely.

b. With the regulation and management of energy management and the implementation of good strategies, China is not overwhelmed in the face of the global fuel crisis which tends to rise.

c. The agreement in contracts for Iran and Iraq is lower compared to Libya and Egypt especially those related to longer "cost recovery", not a matter of the form of the contract.

Daniel Johnston, (2004), science of petroleum engineering is always one step ahead in analysis and design compared to other sciences. One of its key aspects that is never left out is its standard terminology with the fiscal analysis system. Sometimes people use the term "Shared Fund" to identify income components not profit.

The government often lost information during a period of exploration and the focus of calculation then shifts to Internal Rate of Return. From all the problems found in the production sharing contracts for many countries, the most staggering problem lies in the articles of the contracts, and until a contract is agreed upon by all parties, the contract and all contracts must be first reviewed by an accountant or a group of accountants or a consultant to protect the economic interests of the country whose oil and gas belongs to.

William D. Nordhaus (1980) conducted a study on energy economic policy with the title "Oil and Economic Performance in Industrial Countries." Researchers conducted research on a realistic style of energy economics and energy policy, a policy that is not attractive compared to other more populist policies.

In making policies there are three things that must be done by oil and gas observers, namely: First, analysis of the assumption that there are no sanctions for the response of oil producers to energy policies. Second, OECD countries will not act without reference to "optimal" oil taxes. Third, simplifying a more realistic model with the model for each policy and assumption of a review of efficient oil taxes.

From this research it can be seen that to be able to increase state revenues collectively, it can be done by reviewing several policies such as taxation policies, both direct and indirect 
taxes. Because lower taxes will stimulate investors to make investments which ultimately drives the level of production of the oil and gas sector.

\section{RESEARCH METHODS}

This research is qualitative explanative. The hypothesis proposed in this study is: How to manage Oil and Gas Industry based on managerial perspective

Respondents' answers are categorized based on answers where each answer has a gradation from very positive (agree) to very negative (disagree) ranging from score 1 to very no effect until score 5 for being very influential. Furthermore, to categorize the average respondent's answers, an interval scale is calculated which is calculated from the highest score minus the lowest score divided by five answer categories, then an interval for each category of 0.8 is obtained.

The population in this study is the Oil and Gas Management Agency abbreviated with SKK MIGAS overseeing 95 Cooperation Contract Contractors (KKKS), 18 JOB / JOA and 5 TACs in which as many as $44 \mathrm{KKKS}$ have produced

The population of this study are employees who work at KKKS and BP MIGAS at the level of managers, professionals and researchers from tertiary institutions, with the composition as shown in Table 1 the following:

Table 1 Composition of the Study Population

\begin{tabular}{|l|l|l|l|l|l|}
\hline \multirow{2}{*}{ Population } & \multirow{2}{*}{ Amount } & \multicolumn{3}{|l|}{ Years of Service } \\
\cline { 3 - 6 } & & $\mathbf{2 0}$ & $\mathbf{1 5}-\mathbf{2 0}$ & $\mathbf{1 0}-\mathbf{1 5}$ & $\mathbf{5}-\mathbf{1 0}$ \\
\hline Level Manajer & 62 & 31 & 17 & 11 & 3 \\
\hline Professional & 51 & 21 & 6 & 16 & 8 \\
\hline Collage & 18 & 0 & 8 & 10 & 0 \\
\hline Total Population & 131 & 52 & 31 & 37 & 11 \\
\hline
\end{tabular}

The sample is determined through 3 stages, namely (1) cluster sampling, (2) quota sampling, and (3) random sampling.The contract of cooperation contracts that became the sampling area of this study all numbered 44 companies with three working areas (regions I, II and III)

Data were collected by means of observation, interviews, documentation and closed questionnaires To examine the variables that define a factor that cannot be Measured directly, confirmatory factor analysis is used, where this analysis is to give meaning to the latent variables that are confirmed. After that the model interpretation and modification is done.

\section{FINDING AND DISCUSSION}

The general picture of the oil and gas industry in Indonesia is actually closely related to the economic situation in the country and in Southeast Asia and the price of crude oil that prevails in the international market.

Although oil and gas are traded internationally, the meeting points between supply and demand in each country are not the same, for example for the Southeast Asia region, the current level of oil and gas consumption is $40 \%$ exceeding production levels. This means that 
the need for oil and gas for the Southeast Asian region is very high, so that every barrel of oil and gas will be sold at a favorable price.

The method of recording or accounting for oil in Indonesia is not yet very popular, this is because the specificity or nature and characteristics of the oil and gas industry are different from other industries.

The nature and characteristics of oil and gas are different from other industries. The process of finding oil and gas is a chancy activity, meaning that oil and gas exploration activities do not necessarily produce results, while the costs incurred for these purposes are very large. Another characteristic that is also very unique is that oil and gas are goods that cannot be reproduced (renewal).

With the characteristics of the oil industry in such a way, there are several special accounting treatments for the oil and gas industry that are different from the others, the differences include (Statement of Oil and Gas Accounting Standards No.29; 2009: 29.2) as follows:

1. The gambling nature of the exploration business has led to alternatives in the use of cost recognition for reserves that do not contain oil or gas (dry holes).

2. There is an opinion which states that the recognition of costs must be linked to activities until the discovery of oil or gas reserves in a country, so that all costs incurred deferred and will be capitalized as part of oil reserves found in that country.

3. Another opinion says that the costs incurred for the search for oil and gas must be related to the results of the search for a reserve. These costs in fact contain oil or gas and vice versa will be stated as an expense if the reserves do not contain oil or gas.

The existence of special treatment for this upstream industry, which in turn becomes a dilemma in recording (accounting dilemmas). Horace R. Brock (1996: 8) states that basically oil and gas exploration and production activities create many accounting problems encountered in the field, including:

- Should exploration preparation costs be recorded as assets or costs when no rights or leases are obtained?

- Provide an assessment of the low success rate of exploration wells, are these costs considered asset costs or expenses? Does the need for a dry hole be capitalized as a cost of finding oil or gas reserves? For example, a company drills 5 (five) exploration wells at a cost of $\$ 1$ million / well, but only 1 (one) well is suspected to have oil reserves and the reserves are valued at $\$ 20$ million by the company. Can the company recognize as an asset at a price of $\$ 5$ million as a cost to the entire well and $\$ 1$ million as a cost for a successful well, \$20 million from the price of productive property or with an estimated price?

- The process of oil and gas sales can fluctuate at any time. Therefore, prices to produce oil and gas also fluctuate at any time. Does every fluctuation affect the amount of assets listed in the financial statements?

- If production falls over time and the variation of production depends on the property, how is the recognition of capitalization costs amortized or depreciated?

- Should plug and abandoned costs be calculated or estimated in amortized P\&A costs based on estimated production? 
- If the joint venture company and sells each part in the form of a lease to their respective partners, how is the recognition of the profit and loss on the sale?

With characteristics and accounting records that are different from other industries, the measurement of financial performance of an oil and gas exploitation and production industry that will be used as the basis for analysis is the financial statements.

From the financial statements will be known the total production and costs. Increased production and costs (international and domestic) will increase income and return on investment. An increase in the rate of return on investment will increase investment for exploration and is expected to increase the rate of discovery.

To measure how the results obtained from an investment project used indicators of return on investment (Return On Investment abbreviated as ROI). The indicator used to return the investment is done through ROI (Return On Investment) analysis. The relationship between ROI and exploration and oil and gas industry activities is as follows:

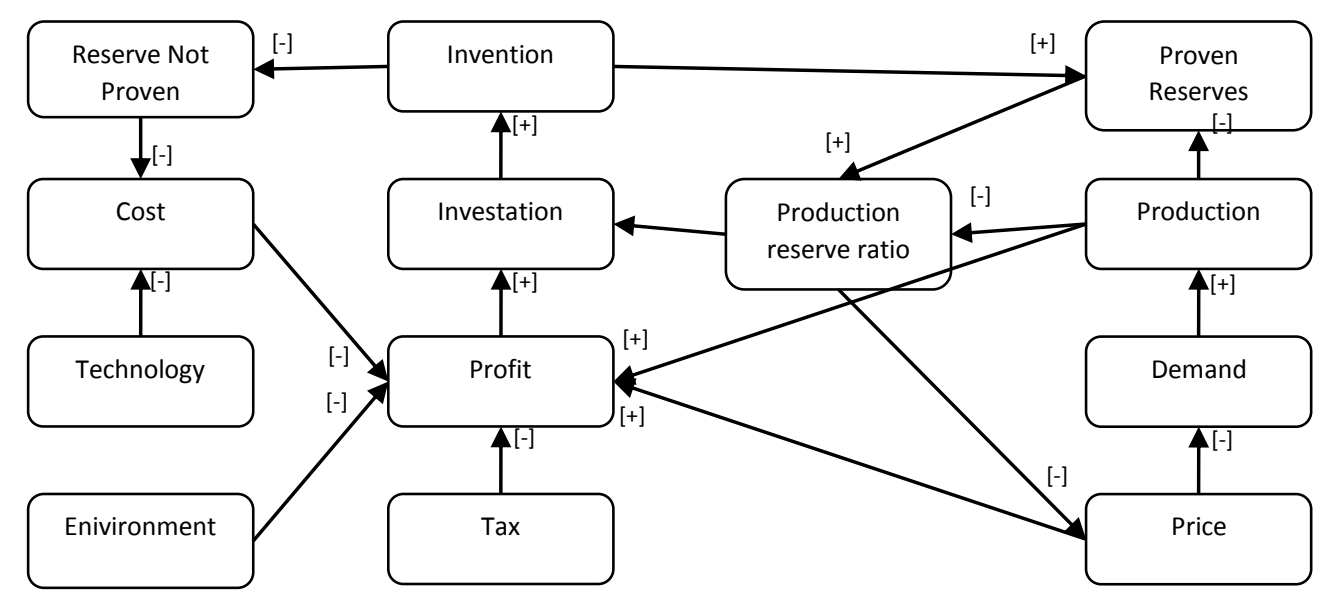

Figure 1 Renewable Energy Exploitation

The limits or definitions of this indicator are very diverse. One definition of ROI is the ratio between net income after tax with total business assets.

One of the profit indicators (ROI) that can be used in the business of non-renewable energy is through the IRR (Internal Rate of Return). IRR is a trial and error condition so as to take into account the time value of money, it does not depend on the absolute value of cash flows, it can be double, it cannot be calculated if all flows are added (+) or not yet returned. Initial cash flow will always be more influential.

The oil and gas exploration and production industry which is capital intensive, uses high technology and is run by skilled workers has the potential for failure or a very high level of risk.

There are several kinds of risks, among others:

1) Price risk - the uncertainty of world oil prices 
2) Political risk - the uncertainty caused by political changes and the intervention of military authorities in several countries.

3) Macroeconomic risk - the existence of uncertainty about fluctuations in currency exchange rates, interest rates and the state of the stock market.

4) Business environment risk - the uncertainty caused by changes and trade and business practices in several countries.

5) The project and asset risk - practices security disturbances to the project being built and company assets.

Based on the above phenomenon, companies in setting policies, especially those related to financial policies, make very careful investments, various performance measurement tools are implemented with the aim of maximizing profits and minimizing risk and expenditure.

\section{Petroleum Accounting}

The Indonesian Institute of Accountants (IAI) on September 7, 1994 issued a statement specifically intended for petroleum business in which in its scope and application it was explained that (PSAK No. 29, 1994: 29.3.):

1) Statement of Oil Accounting Standards and Natural gas. This statement is prepared based on the nature and characteristics of the Indonesian oil business and is guided by the basic accounting concepts contained in Financial Accounting Standards and applicable laws and regulations.

2) This statement is intended to be used as a guide in the presentation of financial statements for external parties. In this sense, an assumption is implied that both the compilers and users of financial statements need the same standard in the preparation and presentation of company reports.

3) This statement regulates the accounting for exploration or search, development, production, processing, transportation, marketing and other activities in the oil and gas industry.

4) For oil and gas contractors working according to contracts with the government / Pertamina, this statement can be used as long as the accounting treatment is not specifically regulated in the contract concerned. In the event that the contract specifically regulates the accounting treatment of a transaction, the contract conditions apply.

In carrying out oil and gas exploration and production activities, there are 4 (four) components of costs that generally occur in oil companies, and the recording is carried out based on the prerequisites that exist in Petroleum Accounting. The four general costs are:

1) Acquisition costs (acquisition costs) Acquisition costs are costs incurred in connection with the company's business to acquire property (the right to conduct the oil and gas industry in an area / area).

2) Exploration costs (exploration costs) Exploration costs are costs incurred in an effort to explore (look for oil and gas and geothermal)

3) Development costs Development costs are costs incurred in relation to activities to prepare / obtain proven reserves (proven reserves) to be ready for commercial production. 
4) Production costs Production costs are costs associated with lifting oil, natural gas, geothermal and other minerals to the surface which consist of first, second and third stages of drainage cost, collection in landfill tanks, separation of oil, natural gas and water-based deposits, treating and storing oil and gas in storage tanks to be ready for market.

The important issue in recording these four cost components is when these costs must be capitalized or when these costs are considered as expenses (charged to current year's profit or loss).

Gallun, RA (1993: 36) says that there are two generally accepted historical cost methods that can be used as the basis for recording costs, namely successful efforts accounting (SE) and full cost accounting (FC).

Based on Generally Accepted Accounting Principle (GAAP) and Statement of Financial Accounting Standards (PSAK) No.29 there are only two recognition methods that can be used, namely:

1. Full costing (FC) Method

2. Successful Effort (SE) Method

The emergence of this thinking is caused by various matters which have caused controversy among the oil industry, especially those concerning accounting treatment of exploration activities and costs which are full of speculation elements.

The main issue here is whether exploration costs during the unsuccessful or unsuccessful search for oil and gas are the costs of a successful search for oil and gas.

In America, oil and gas accounting standards issued by the Financial Accounting Standard Board (FASB) are also called the Standard Financial Accounting Statement (SFAS 19.25, and 69), making restrictions that can be used as a reference in recording and reporting. It regulates when the Successful Effort Method is used and who can use the Full Costing Method.

\section{Full Costing (FC) Method}

According to Daniel Johnston (1992: 57) Full cost accounting has been developed since the 1950s. The first company to use Full Cost was Belco Petroleum in 1957, sometime before it entered the stock market. FC is used by small companies and especially those just starting to enter the stock market. This company believes that this system is very fair.

With the issuance of SFAS 19, several parties, especially small and newly established oil and gas producers are of the opinion that a failed search for oil and gas is the cost of a successful search for oil and gas.

On the grounds that the costs from sources that fail to produce oil and gas (dry hole) are included as part of the costs required to obtain oil and gas holes that produce oil and gas and are profitable.

Thus the exploration costs of the dry hole must be capitalized with the source of the produce. This concept is called the Full cost concept (FC). 


\section{Successful Effort Concepts (SE)}

SFAS 19 issued by the FASB regulates financial accounting and reporting for US oil and gas companies. Then the FASB issued SFAS 25 which basically allowed the use of FC Concepts in accounting for oil and gas exploration in addition to the SE Concepts.

Even though the FASB has issued SFAS 25, which corrects SFAS 19, the controversy continues and the SEC considers that both FC Concepts and SE Concepts still do not provide sufficient information on the financial position and results of operations of oil and gas companies.

For this reason, the SEC is of the view that it is necessary to develop suitable accounting methods from successful oil sources. Furthermore, the SEC came up with the concept of Reserve Recognition Accounting (RRA), which later included the background of the birth of SFAS 69. SFAS 69 asked oil and gas companies to disclose additional information but did not form part of the financial statements consisting of:

a. Number of successful oil and gas sources

b. Capitalized oil and gas production costs

c. Costs of acquisition, exploration and development activities for oil and gas

d. The results of oil and gas production activities

e. Standard size of discounted future cash flow for oil and gas sources

Based on attachment " $\mathrm{C}$ " in the cooperation contract on Accounting Procedures, which is a detailed explanation of the terms of the costs contained in the contract, if there is a mismatch between the Appendix Accounting and the production sharing contract, the fee provisions apply which is set in the section operating cost.

In preparing the accounting system and financial statements must be in accordance with Generally Accepted and Recognized Accounting Systems, with the aim of being able to describe the receipt of operating costs from the sale of crude oil and must be consistent with oil industry practices and present as detailed in the appendix to accounting procedures.

From the phenomenon of recording method, it is found that three references are the basis for recording, namely General Accepted Accounting Principles, Financial Accounting Standards Guidelines and Generally Accepted and Recognized Accounting Systems, and there are two methods of treatment of costs incurred by an oil and gas exploitation and production activity in Indonesia. In order to obtain clear and transparent information and avoid different interpretations between the contractor of the cooperation contract and the government, then in the oil and gas cooperation contract, the principles and accounting methods used must be firmly determined and the desired accounting period to be the same as the records made in STATE BUDGET.

From the results of the study, the researcher tried to make a comparison of the application of accounting principles used by the contract cooperation contractor in making financial reports for reporting needs to the Indonesian government using the PSC Accounting format while for reporting to the parent company using US GAAP. 
The difference that can be seen from the application of PSC Accounting with US GAAP is as follows:

Table 2 Comparison of PSC Accounting vs. US GAAP

\begin{tabular}{|c|c|c|}
\hline AREA & PSC Accounting & US GAAP \\
\hline Amortization of capital cost & Accelerated depreciation & Units of production amortization \\
\hline $\begin{array}{c}\text { Non-capital/controllable } \\
\text { stores }\end{array}$ & Expensed upon receipt & Expensed as consumed \\
\hline $\begin{array}{c}\text { Obsolete stores or idle } \\
\text { facilities }\end{array}$ & $\begin{array}{l}\text { Written off only when } \\
\text { approved by BPMIGAS }\end{array}$ & Expensed when identified \\
\hline Deferred taxes & Not provided & SFAS 109 treatment \\
\hline Contingent liabilities & $\begin{array}{c}\text { Recognized when settled or } \\
\text { approved by BPMIGAS }\end{array}$ & SFAS 5 treatment \\
\hline $\begin{array}{c}\text { Severance And Retirement } \\
\text { benefits }\end{array}$ & Pay as you go basis & SFAS 87 treatment \\
\hline Pre-production cost & $\begin{array}{l}\text { All costs capitalized pending } \\
\text { cost recovery }\end{array}$ & A portion of costs capitalized \\
\hline Abandonment & $\begin{array}{c}\text { Recorded and recovered on } \\
\text { cash basis }\end{array}$ & $\begin{array}{l}\text { Provided for on a units of } \\
\text { production basis }\end{array}$ \\
\hline
\end{tabular}

Petroleum analysts understand that accounting methods have an impact on financial statements. Income for companies that use FC is generally not the same compared to companies that use SE. Companies that use FC pay a price to get a relatively higher opportunity. They must pay higher taxes (Johnston, D, 1998: 37)

Analysis in evaluating assets ignores differences in accounting methods used whether FC or SE, their concern is cash flow (Johnston, D et al, 1998: 38).

The limits or definitions of this indicator are very diverse. One definition of ROI is the ratio between net income after tax with total business assets.

One of the profit indicators (ROI) that can be used in the business of non-renewable energy is through the IRR (Internal Rate of Return). IRR is a trial and error condition so as to take into account the time value of money, it does not depend on the absolute value of cash flows, it can be double, it cannot be calculated if all flows are added (+) or not yet returned. Initial cash flow will always be more influential.

The oil and gas exploration and production industry which is capital intensive, uses high technology and is run by skilled workers has the potential for failure or a very high level of risk.

There are several kinds of risks, among others:

1) Price risk - the uncertainty of world oil prices

2) Political risk - the uncertainty caused by political changes and the intervention of military authorities in several countries.

3) Macroeconomic risk - the existence of uncertainty about fluctuations in currency exchange rates, interest rates and the state of the stock market.

4) Business environment risk - the uncertainty caused by changes and trade and business practices in several countries. 
5) The project and asset risk - practices security disturbances to the project being built and company assets.

Based on the above phenomenon, companies in setting policies, especially those related to financial policies, make very careful investments, various performance measurement tools are implemented with the aim of maximizing profits and minimizing risk and expenditure.

\section{CONCLUSION RECOMMENDATIONS}

From the description above relating to oil management which includes oil accounting, theoretically it is seen here that in the operation of the oil and gas industry, a very large source of funds is needed.

To manage this source of funds, a system that is synchronous between technological capability and expertise is needed so that the possibility of experiencing the risk of loss can be minimized.

Management is responsible for establishing and maintaining disclosure of company controls and procedures, so that the management process in petroleum management can coordinate well, we need an accounting system that can support the activities of finding, discovering, developing and producing oil and gas efficiently and effectively and can be accounted for . This responsibility is intended that in carrying out its operations the company has followed the rules and procedures that exist in oil accounting that are generally accepted and according to accounting standards.

\section{Recommendations}

1) To improve the oversight function of the public, PSAK No. 29 on Oil and Gas needs to be reviewed and adjusted to Oil and Gas Law No. 22 of 2001.

2) Provided an integrated system between exclusive rights holders in this case the government and the contractor in order to get the maximum benefit from this nonrenewable industry.

3) Strict sanctions for violators of cooperation contracts, especially those related to Cost Recovery so that costs incurred by the government can be minimized

4) To the Central Government in this case the Department of Energy and Mineral Resources and BP MIGAS should deliver the production produced by each producing region based on production or lifting reports that actually occur quarterly to the producing regions..

\section{REFERENCE}

Asmawi. (2008, April 22). Price of oil and gas, Riau Pos, p. 1.

Barata, A.A. dan B.Trihartono, 2004, Kekuasaan Pengelolaan Keuangan Negara/Daerah, ISBN 234040883, Gramedia, Jakarta.

Brock, H.R. D.R.Jennings, and J.B Feiten. 1996. Petroleum Accounting : Principles Procedures \& Issues. Fourth edition. ISBN 00940966-24-7. Professional Development Institute, Texas.

Djojohadikusumo. S. 1994, Dasar Teori Ekonomi Peltumbuhan dan Ekonomi Pembangunan, ISBN 979-8391•26-6, Pustaka LP3ES Indonesia, Jakarta

Johnston, D. 1994, International Petroleum Fiscal Systems and Production Sharing Contracts, ISBN 0-87814-426-9, PennWell Publishing Company, Tulsa.p.51 
Julianti. W, 2002, Share Fund Material Seminar, ESDM, Jakarta. p.3.

Gallun, R.A. JW. Stevenson and LM. Nicholas. 1993. ISBN 0-87814-404-8, Fundamentals of Oil \& Gas Accounting, third edition, Pennwell books, Tulsa

Oetomo. (2004, October 21). Standard Price of oil and gas, Kompas, p. 6.

Patowidagdo, W, 2002, Manajemen dan Ekonomi Minyak dan Gas Bumi, ISBN 979-957462-5, Program Studi Pembangunan PPS ITB, Bandung. P.80

Rezky Sri Wibowo, 2005, Transparansi Ekonomi Ekstraktif Di Indonesia, Journal Transparency International Indonesia, Jakarta p.65

Sutadi P.U, 2002, PSC Contractual System Course, LDI Training, Yogyakarta.

Sugiyono, 2001, Metodo;ogi Penelitian, AlfaBeta, Bandung.

Sanusi, B. 2002, Perenan Migas dalam Perekonomian Indonesia, ISBN 979-8398-46-7, PenerM Univers a s Trisakti, Jakarta.

- - - . 2004, PoIensi Ekonomi Migas Indonesia, ISBN 979-518-872-0, Rineka Cipla, Jakarta.

Siregar, D. D. 2004, Manajemen Aset, ISBN 979-22-0761.9, Gramedia Pustaka Ulama, Jakarta.

Sidik, Machfud. and B.R.Mahi, 2002, Dana Alokasi Umum, Konsep Hambatan dan Prospek di Era otonomi Daerah, ISBN 979-709-048-5, Penerbil Buku Kompas, Jakarta.

Subiyantoro, H. 2004. Kebijakan Fiskal: Pemikiran, Konsep, dan Implementasi. Jakarta. Penerbit Buku Kompas.

Suparmoko, M, 1997, Ekonomi Sumberdaya Alam dan Lingkungan, ISBN 979-503--305•0, BPFE Yogyakarta, Yogyakarta.

Sutadi, P. 1999. PSC Contractual System. Yogyakarta. LDI Training

- - --- , 2004, Mengenal Pembengunan dan Analisis Kebijakan, ISBN 979•95746-Q..9, Program Studi Pembangunan PPS ITB, Bandung

" 2002, Ekonomi Publik, ISBN 979•533--792-0, ANDI Offset, Yogyakarta. 2003. International Exploration Economics, Risk and Contract Analysis. Tulsa.

Pennwell Publishing Company. . 1992. Oil company, Financial Analysis in Nontechnical Languange. Tulsa. Pennwell

Publishing Company. 1998. International Oil Company Financial Management In Nontechnical Languange. Tulsa. Pennwell Publishing Company. 2004. Mengenal Pembangunan dan Analisis Kebijakan. Bandung.Program Studi Pembangunan PPS ITB 